\title{
A Case of Lactobacillus Bacteremia during Probiotic Supplementation in a Very Preterm Infant with Short Bowel Syndrome
}

Seon Nyo Kim, M.D., Hae Yun Lee, M.D., Saeyun Kim, M.D., Byung kook Lee, M.D., Young Hwa Jung, M.D., Joosun Huh, M.D., Jae-Gu Seo, Ph.D.*, Seung Han Shin, M.D., Ee-Kyung Kim, M.D., Ph.D., Han-Suk Kim, M.D., Ph.D., and Jung-Hwan Choi, M.D., Ph.D.

Department of Pediatrics, Seoul National University College of Medicine, Seoul, Korea R\&D Center*, Cell Biotech Co., Ltd., Gimpo, Korea

\section{ABSTRACT}

Probiotics are living micro-organisms that beneficially affect the composition of the host intestinal microflora. In very preterm infants, probiotics reportedly help reduce necrotizing enterocolitis (NEC), invasive fugal colonization and sepsis, and enable the establishment of complete enteral feeding at an earlier stage. However, emerging evidence has indicated the risk of potential side effects of probiotic use, such as gut organism translocation, including probiotic organisms, in infants that are more premature. In the present report, we describe a case of Lactobacillus bacteremia in a very preterm infant with short bowel syndrome. Lactobacillus sepsis developed during the therapeutic use of this organism for diarrhea and diarrhea-related malabsorption. The organism isolated from the blood sample was found to be of the same strain as that administered, by using molecular techniques. The findings of the present case suggest that probiotics should be carefully used, particularly in very preterm infants with altered intestinal permeability such as short bowel syndrome.

Key Words: Probiotics, Lactobacillus, Very preterm infant, Short bowel syndrome, Bacteremia

서론

현재 임상에서 널리 사용되고 있는 정장제(probiotics)는 살아있는 미생물로 숙주의 장내 세균총을 이롭게 변화시켜 주는 것으로 알려져 있다1). 미숙아에서 probiotics의 사용에 관한 연구는 활발하게 이루어져 왔으며, 심한 괴사성 장염을 감소시키고, 극소 저체중 출생아 및 미숙아에서 위장관계 질환의 이환율 및 사망률을 낮추며23), 식이진행을 호전시켜 병원 재원 기간을 낮춘다고 알려져 있다 ${ }^{4}$.

하지만 살아있는 미생물을 투약함에 따르는 위험을 고려해야 하는데, 실제로 장 절제 후
Received: 15 June 2015

Revised: 4 August 2015

Accepted: 4 August 2015

Correspondence to:

Han-Suk Kim, M.D., Ph.D.

Department of Pediatrics, Seoul

National University College of

Medicine, 101 Daehak-ro, Jongno-

gu, Seoul 03080, Korea

Tel: +82-2-2072-3778

Fax: +82-2-2072-3917

E-mail: kimhans@snu.ac.kr

Copyright(c)

By Korean Society of Neonatology.

All right reserved.

This is an Open-Access article distributed under the terms of the Creative Commons Attribution Non-Commercial License (http://creativecommons.org/licenses/ by-nc/3.0), which permits unrestricted non-commercial use, distribution, and reproduction in any medium, provided the original work is properly cited. 
Saccharomyces boulardii (S. boulardii)를 투약한 환자에서 $S$. boulardii에 의한 진균혈증의 사례가 보고되었으며5), 단장증후군 환자에서 Lactobacillus (LGG)투약 후 probiotics와 동일한 균에 의한 패혈증이 3례 보고된 바 있다6.7). 본 저자들은 단장증후군을 가진 초미숙아에서 probiotics의 투약 후 probiotics와 같은 균주 가 동정된 1례를 경험하여 보고하는 바이다.

증례

환자는 조절되지 않는 조기산통으로 응급 제왕절개를 통해 임 신기간 23주 6일, 출생체중 $500 \mathrm{~g}$ (3-9 percentile)으로 출생한 여 아로, 아프가 점수는 1분에 2점, 5 분에 4점이었다. 산모는 Para 1-0-2-1인 28세로 기저 질환, 약물 복용 등의 특이 병력 없었다. 조기 양막 파수 없었으나, 임신기간 23주 1일에 성병 선별검사에 서 Trichomonas Vaginalis 양성으로 항생제(Klaricid XL ${ }^{\circledR}, \mathrm{Ce}-$ ftriaxone $^{\circledR}$, Metronidazole ${ }^{\circledR}$ 를 투약하던 중 23주 5일 조기산통 발생하여 산전 베타메타손(betamethasone)을 투여 받았다. 환 자는 출생 당시에 자발호흡은 없었고, 서맥이 관찰되어 기관삽관 을 하였으며, 인공 폐표면활성제를 투여 받은 후 신생아중환자실 에 입원하였다.

신생아중환자실 입실 후 고빈도환기요법을 시작하였고, 제대 동 맥관과 정맥관을 삽입하였으며, 생후 2일째 trophic feeding 시작 하였고, 생후 6 일째 제대 정맥관 제거 후 말초정맥을 통한 중심정 맥관(percutaneous central venous catheter, PCVC)을 삽입 하 였다. 생후 7일째 제대 동맥관 제거하였고, 생후 8일경 동맥관개존 증 결찰술을 시행하였다. 당시에 지속적으로 태변을 보지 못하면 서 복부팽만 소견 관찰되었으며, 복부 초음파 상에서 태변으로 인 한 폐쇄 소견 있어 gastrograffin 관장을 시행하였다. 익일 시행한 단순방사선사진에서 장 천공이 관찰되어 개복술을 시행하고, 공 장과 회장에 각각 장루술을 시행받았다. 이 후 식이증량하며 관찰 하는 중 식이 진행이 잘 되지 않고, 장루의 배액량이 증가되어 중 심정맥관으로 정맥영양 병행하였고, 생후 47일에 hypoallergenic, amino-acid based formula (HA)로 식이를 변경하여 생후 81일 째 $120 \mathrm{cc} / \mathrm{kg} / \mathrm{day}$ 까지 증량되었다.

생후 85일 장루의 배액량이 증가하고, 빈번한 무호흡이 관찰되 어 시행한 혈액배양 검사 상 동정된 균은 없었다. 증상 지속되어 생후 91일에 시행한 혈액배양 검사의 중간보고에서 yeast like cell 확인되어 amphotericin B $1 \mathrm{mg} / \mathrm{kg} / \mathrm{day}$ 로 투약 시작하였다. 최종 보고에서 Candida parapsilosis 동정되었으며, 항생제 감수성을 반영하여 caspofungin $25 \mathrm{mg} / \mathrm{m}^{2} / \mathrm{dose}$ 로 변경하여 매일 1회 정 주하였다. 생후 105일째 증상이 호전되고 복부초음파에서 이상 소견 발견되지 않아 다시 식이를 진행하였다. 이후 소화되지 않는
양상 지속되어 부분적으로 중심정맥관으로 총정맥영양 유지하였 고, erythromycin 및 probiotics (Duolac $\left.{ }^{\circledR}\right) 1 \mathrm{~g}$ 매일 1회 투약을 시작하여, 생후 120 일에 식이는 $50 \mathrm{cc} / \mathrm{kg}$ /day까지 진행되었다.

생후 121 일에 다시 반복적인 구토가 관찰되어 식이를 중단하였 고, 당시 시행한 말초혈액검사에서 백혈구 $5000 / \mathrm{mm}^{3}$ (호중구 $50 \%$, 호염기구 3\%, 림프구 $17 \%$, 단핵구 $26 \%$, 호산구 $4 \%)$, 혈색소 $9.9 \mathrm{~g} / \mathrm{dL}$, 혈소판 133,000/ $\mathrm{mm}^{3}$ 이었고 C-reactive protein (CRP $1.28 \mathrm{mg} / \mathrm{dL})$ 의 상승을 보여, 패혈증 의심 하에 항생제(Tazocin ${ }^{\circledR}$ 과 $\mathrm{Amikin}^{\circledR}$ ) 투여를 시작하였다. 생후 126일에 말초 혈액배양검 사 1쌍에서 $\beta$-Lactamase 음성인 Lactobacillus 동정(Figure 1)되 었으며, Amikin ${ }^{\circledR}$ 및 복용 중인 probiotics는 투약 중단하였고, 중 심정맥관을 제거하였으며, 배양검사 음전으로부터 2주간 Tazo$\operatorname{cin}^{\circledR}$ 투약을 유지하였다.

당시 배지에서 분리된 균주를 이용하여 genomic deoxyribonucleic acid (gDNA)를 이용한 interaction-dependent polymerase chain reaction (ID-PCR)와 16s ribosomal ribonucleic acid(rRNA) 염기서열 분석 시행하였으며, Lactobacillus planta-

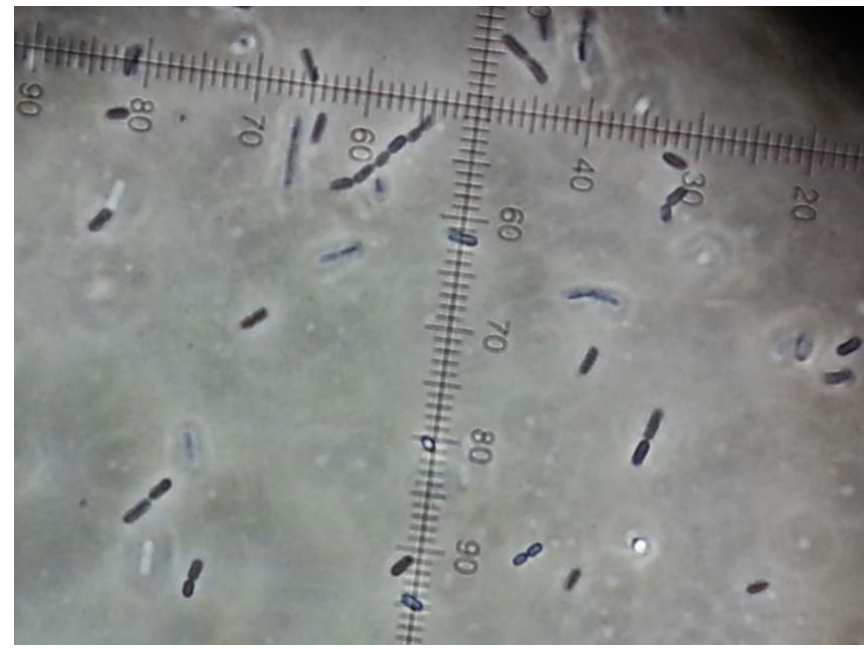

Figure 1. Gram staining of Lactobacillus plantarum, isolated from the patient $(\times 1,000, \mathrm{BX} 51$, Olympus).

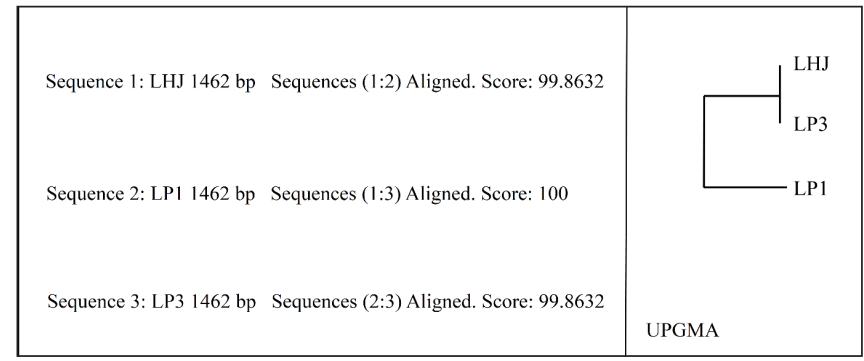

Figure 2. Multiple sequence alignments of a partial 16s rRNA sequence. Abbreviations: LHJ, patient; LP1, Lactobacillus plantarum 1; LP3, Lactobacillus plantarum 3; UPGMA, unweighted pair group method with arithmetic mean. 
rum으로 확인하였다(Figure 2). 16s rRNA partial sequence에 대 한 multiple sequence aligment와 random amplified polymorphic polymerase chain reaction (RAPD-PCR) band pattern 비 교하여 환자에게 투약한 probiotics와 동일한 Lactobacillus plan tarum 3 (LP3)임을 확인하였다.

환자는 생후 152 일에 회장의 장루 복원술 시행하였고, 생후 210 일에는 공장의 장루 복원술을 시행하였다. 이후 식이 진행이 원활 하게 되어 총정맥영양을 끊고, 교정주수 21주 6일인 생후 268일째 체중 $4.91 \mathrm{~kg}$ 으로 퇴원하였다.

\section{고찰}

본 증례는 단장증후군으로 신생아집중치료를 받던 환자에게서 복용 중이던 probiotics로 인해 패혈증이 발생한 경우로 볼 수 있 다. 단장증후군은 수술적 절제, 선천성 결함 또는 장의 흡수 능력 소실과 관련된 질병의 결과로, 정상적인 식이로 전해질 조절 및 영 양소의 흡수 등이 어려워져 총정맥영양에 의존하게 된담. 미숙아 에서의 단장증후군의 정의는 확립되어 있지는 않지만, 개복술을 받은 신생아에서 재태주령에 예상되는 장 길이의 $25 \%$ 미만이 남 아있는 경우9) 또는 수술 후 위장관 불내성으로 42 일 이상 경장관 영양이 필요한 경우를 의미한다미. 이러한 환자에서 probiotics는 탄수화물 발효를 촉진하여 짧은 사슬 지방산의 생산을 증가시켜 장의 적응을 개선시키고 ${ }^{11,12)}$, probiotics가 장점막 표면의 부착부 위에서 병원균의 부착을 저해하거나 장벽의 완전성을 증진시키는 인자의 분비를 돕는 등의 방법으로 장점막 장벽의 증진을 돕는 것 으로 알려져 있다 ${ }^{13,14)}$. 이 외에도 probiotics는 항균물질을 생성하 여, 균의 집락 형성을 저해하는 것으로 보고된 바 있으며, 특정 세 균의 과 증식을 억제하고 정맥 영양 기간을 단축시키는 효과가 있 다는 주장도 제기되고 있다 ${ }^{15,16)}$. 또한, 변의 수분 함유의 감소로 변 의 굳기가 호전되는 효과를 나타내며, 궁극적으로는 성장과 영양 에 긍정적인 효과를 가지고 있는 것으로 알려져 있다 ${ }^{17,18)}$.

그러나 살아있는 균주를 투약함으로 인한 부작용이 보고되었 는데, Lactobacillus 균주를 투약한 그룹에서 투약된 probiotics 와 동일한 균주로 인한 패혈증6,7)이 보고되었으며, Lactobacillus acidophilus 와 Bifidobacterium infantis가 함유된 probiotics를 투약한 뒤 D-젖산 산증이 관찰되었다. 이는 probiotics를 중단하 면서 호전 되었으며, 우연히 재투약하였을 때 $\mathrm{D}$-젖산 산증이 재 발생하는 것을 관찰할 수 있었다 ${ }^{19)}$. 특히, probiotics로 인한 패혈 증에 대한 보고는 면역이 저하되어 있거나 초미숙아20) 또는 장의 투과성이 변할 수 있는 단장증후군과 같은 질환을 가진 환자에서 보고되었으며7), 장점막이 완전히 발달하지 않은 취약한 개체군인 초미숙아에서의 probiotics의 투약은 장의 투과성 증가로 인해 패
혈증이 발생하였을 것으로 생각되며, 이번 증례의 경우 Lactobacilli의 작용기전 중 하나인 부착 능력의 증가 또한 그 원인으로 작용하였을 것으로 보여진다.

본 증례의 환자도 단장증후군으로 식이진행이 잘 되지 않아, 치 료 목적으로 probiotics를 투약하였으나 투약한 제제와 동일한 균 으로 인한 패혈증이 관찰되었으며, 이것의 원인은 두 가지로 나눠 생각해볼 수 있다. 첫째, 앞서 언급한 증례와 같이 단장증후군으 로 인한 장의 투과성 증가 및 Lactobacilli의 작용기전인 부착 능력 의 증가로 인한 것으로 생각할 수 있다. 둘째, 총정맥영양 공급을 위한 중심정맥관을 삽입하고 있던 상태로 이를 통한 패혈증의 가 능성을 고려해볼 수 있다. 그러나, 장점막을 통한 감염의 가능성이 더 높을 것으로 보이는데, 이는 중심정맥관의 혈액배양 검사 및 삽 입되었던 관의 배양검사에서 이상소견이 없었으며, 중심정맥관의 관리는 적절하였고, 중심정맥관 삽입과 식이진행을 위해 삽입된 영영관은 따로 떨어져 관리되었기 때문이다.

앞선 probiotics의 안정성 및 효과에 대한 연구는 대부분 정상 영아를 대상으로 한 것으로 장의 투과성이 변하는 질환을 갖고 있 거나, 면역이 억제 또는 저하된 환자, 중심정맥관을 가진 환자에서 probiotics의 투약은 조심스러워야 할 것으로 생각된다.

또한, 단장증후군 환자에서 probiotics의 투약에 대한 안정성 및 효과, 부작용과 관련하여 대규모 연구는 없는 상태로 향후 전 향적인 연구가 필요하며, 이를 통하여 단장증후군 환자에서 안전 하고 효과적인 probiotics 균주, 용량, 투여시작시점과 기간에 대 한 가이드라인의 제시가 필요하다.

저자들은 국내에서는 처음으로 단장증후군을 지닌 초극소 저 출생 체중아에서 probiotics와 동일한 균주인 Lactobacilli 패혈증 을 경험하여 보고하는 바이다.

\section{감사의 글}

본 연구의 균주 분석을 진행해주신 Cell Biotech Co., Ltd. 연구 원께 감사를 드립니다.

\section{REFERENCES}

1) Food and Agriculture Organization of the United Nations, World Health Organization. Report of a joint FAO/WHO expert consultation on evaluation of health and nutritional properties of probiotics in food including powder milk with live lactic acid bacteria. Rome, Italy: Food and Agriculture Organization of the United Nations; 2001.

2) Hartel C, Pagel J, Rupp J, Bendiks M, Guthmann F, Rieger- 
Fackeldey E, et al. Prophylactic use of Lactobacillus acidophilus/Bifidobacterium infantis probiotics and outcome in very low birth weight infants. J Pediatr 2014;165:285-9.e1.

3) AlFaleh $\mathrm{K}$, Anabrees J. Probiotics for prevention of necrotizing enterocolitis in preterm infants. Evid Based Child Health 2014; 9:584-671.

4) Rojas MA, Lozano JM, Rojas MX, Rodriguez VA, Rondon MA, Bastidas JA, et al. Prophylactic probiotics to prevent death and nosocomial infection in preterm infants. Pediatrics 2012; 130:e1113-20.

5) Thygesen JB, Glerup H, Tarp B. Saccharomyces boulardii fungemia caused by treatment with a probioticum. BMJ Case Rep 2012. doi: 10.1136/bcr.06.2011.4412.

6) De Groote MA, Frank DN, Dowell E, Glode MP, Pace NR. Lactobacillus rhamnosus GG bacteremia associated with probiotic use in a child with short gut syndrome. Pediatr Infect Dis J 2005;24:278-80.

7) Kunz AN, Noel JM, Fairchok MP. Two cases of Lactobacillus bacteremia during probiotic treatment of short gut syndrome. J Pediatr Gastroenterol Nutr 2004;38:457-8.

8) O'Keefe SJ, Buchman AL, Fishbein TM, Jeejeebhoy $\mathrm{KN}$, Jeppesen PB, Shaffer J. Short bowel syndrome and intestinal failure: consensus definitions and overview. Clin Gastroenterol Hepatol 2006;4:6-10.

9) Touloukian RJ, Smith GJ. Normal intestinal length in preterm infants. J Pediatr Surg 1983;18:720-3.

10) Wales PW, de Silva N, Kim JH, Lecce L, Sandhu A, Moore AM. Neonatal short bowel syndrome: a cohort study. J Pediatr Surg 2005;40:755-62.

11) Floch MH. The effect of probiotics on host metabolism: the microbiota and fermentation. J Clin Gastroenterol 2010;44 Suppl 1:S19-21.
12) Tappenden KA, McBurney MI. Systemic short-chain fatty acids rapidly alter gastrointestinal structure, function, and expression of early response genes. Dig Dis Sci 1998;43:1526-36.

13) Madsen K, Cornish A, Soper P, McKaigney C, Jijon H, Yachimec $\mathrm{C}$, et al. Probiotic bacteria enhance murine and human intestinal epithelial barrier function. Gastroenterology 2001; 121:580-91.

14) Mangell $P$, Nejdfors $P$, Wang $M$, Ahrne $S$, Westrom $B$, Thorlacius $\mathrm{H}$, et al. Lactobacillus plantarum 299v inhibits Escherichia coliinduced intestinal permeability. Dig Dis Sci 2002;47:511-6.

15) Lievin V, Peiffer I, Hudault S, Rochat F, Brassart D, Neeser JR, et al. Bifidobacterium strains from resident infant human gastrointestinal microflora exert antimicrobial activity. Gut 2000;47:646-52.

16) Vanderhoof JA, Young RJ, Murray N, Kaufman SS. Treatment strategies for small bowel bacterial overgrowth in short bowel syndrome. J Pediatr Gastroenterol Nutr 1998;27:155-60.

17) Kanamori $Y$, Hashizume $K$, Sugiyama M, Morotomi M, Yuki N. Combination therapy with Bifidobacterium breve, Lactobacillus casei, and galactooligosaccharides dramatically improved the intestinal function in a girl with short bowel syndrome: a novel synbiotics therapy for intestinal failure. Dig Dis Sci 2001;46:2010-6.

18) Uchida $K$, Takahashi $T$, Inoue $M$, Morotomi $M$, Otake $K$, Nakazawa $\mathrm{M}$, et al. Immunonutritional effects during synbiotics therapy in pediatric patients with short bowel syndrome. Pediatr Surg Int 2007;23:243-8.

19) $\mathrm{Ku} \mathrm{WH}$, Lau DCY, Huen KF. Probiotics provoked D-lactic acidosis in short bowel syndrome: case report and literature review. HK J Paediatr 2006;11:246-54.

20) Zbinden A, Zbinden R, Berger C, Arlettaz R. Case series of Bifidobacterium longum bateremia in three preterm infants on probiotic therapy. Neonatology 2015;107:56-9. 